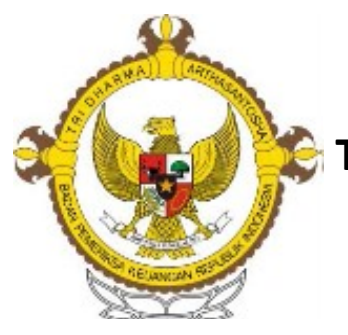

TATA KELOLA \& AKUNTABILITAS KEUANGAN NEGARA

Volume 5, Number 2, Jul-Dec 2019, 157-175

e-ISSN 2549-452X

p-ISSN 2460-3937

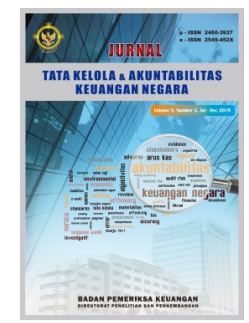

\title{
BUDGET FORECAST ERRORS AND BUDGET DEVIATION: FINANCIAL CAPABILITY INDEX AS MODERATING VARIABLE
}

\author{
Jancen Roland Patty \\ Ambon State Polytechnic \\ yansenpatty@gmail.com
}

\begin{abstract}
The lack of accounting literature that links budget supervision or control with budget realization allows the author to conduct this study. In addition, the main issue of this study is the failure of the local government in planning, implementing and being responsible for the budget resulting in budget surpluses and deficits. Surplus and deficit prove the existence of the budget deviations. The cause of the budget deviation is a mistake in the budget forecast. Some cases of budget deficits in Indonesia prove this. Budget forecast errors have the potential to increase budget deviation due to the role of the financial capability index. The purpose of this study is to examine the role of financial capability index in influencing the relationship of budget forecast errors and budget deviation. The sample used local government in Indonesia between 2016 and 2018 through a purposive sampling technique. Analytical tools use STATA Version 15.1. The results of the study prove that budget forecast errors have a positive and significant effect on budget deviation, and the financial capability index has a positive effect on the relationship between budget forecast errors and budget deviation. Sensitivity testing and additional testing reinforced the initial testing of this study.
\end{abstract}

\section{KEYWORDS:}

Budget forecast errors; financial capability index; budget deviation

DOI: 10.28986/jtaken.v5i2.353 


\section{INTRODUCTION}

Budget oversight is one of the stages in the budget cycle in public sector agencies that has an important role in evaluating the effectiveness of public policies. This is because (1) budget oversight is a process to ensure that planned activities can be carried out properly; (2) compliance with the implementation of the budget by statutory provisions; and (3) provide feedback information about actions that need to be taken if there is a deviation from the target (Siregar, 2017). Furthermore, Siregar (2017) explained that budget oversight cannot be carried out as a special period of supervision stage, but budget oversight is carried out at all stages in the budget cycle, from planning activities to budget accountability. Weakness in budget oversight results in surplus and deficit. That is, surplus and deficit prove that the implementation of budgeting does not increase the effectiveness of public policies and reduce public welfare.

Johansson and Siverbo (2014) state that surplus proves regulators have incompetence and indiscipline in planning, implementing, and budgeting accountability. Wirasedana, Sisdyani, and Setiawan (2018) state that surplus proves budget execution is not politically valid because it is contrary to budget planning. Furthermore, Wirasedana, et al. (2018) state that the implementation of the budget should be able to improve public welfare, thus avoid surplus. The condition of surplus in public sector agencies has resulted in the attention of mass media, nongovernmental organizations and the public. This condition indicates that regulators cannot use public resources that should be used to improve public welfare (Wildavsky, 1975).

Unlike surplus, deficits are difficult to occur in public sector agencies. This is because the process of the budget revision to increase resource allocation requires a long and rigid process (Wirasedana et al., 2018). However, the data proves that deficit has fluctuated for local government over the past three years. Budget realization data from the Directorate General of Fiscal Balance (DJPK) which processed by the authors showed the deficits that occurred in local governments in Indonesia over the past three years were 9 local governments (2018), 226 local governments (2017), and 318 local governments (2016).

Johansson and Siverbo (2014) state that deficits are illegal in some countries and can be punished. Some cases of budget deficits in local governments in Indonesia that are of public concern are the case of the Bekasi City budget and the Badung Regency budget. These conditions occur in both local governments due to high spending without regard to guaranteed revenue to be obtained, thus indicate a weak budget forecast.

Surplus and deficit prove the existence of budget deviation. Budget deviation indicates that the governments fail to plan, implement, monitor, and account for budgets, resulting in budget surplus or deficit. Budget deviation proves that there are conflicts between local governments as the agent that have excess information compared to the community as the principals. This condition occurs because the community can only access information through the publication of financial reports of the local government. Besides, in the political theory of the budget cycle, the budget used as a political tool by regulators. Jonung, Larch, Favero, and Martin (2006) state that deficits occur because of budget forecast errors. In other words, budget forecast errors lead to budget deviations. Erroneous estimation of the budget is budget forecasts that are too high for revenue and/or budget forecasts that are too low for expenditure. 
Boukari and Veiga (2018) state that budget forecast analysis has an important role in economic policy. That is the analysis of budget forecasts used by regulators in implementing economic policies. Auerbach (1999) states that the forecast of revenue is an important input in designing fiscal policy, and the estimation of revenue that is too high (optimistic) causes a loss of public welfare. Repeatedly overestimated revenue forecast and/or underestimate expenditures forecast at the local level can lead to large debt accumulation, whose burden will reduce the available funds for the provision of public goods and reduce public welfare.

Previous study tries to explain budgeting decision-making processes in public sector agencies (Wildavsky, 1975; Jonsson, 1982; Boland \& Pondy, 1986; Covaleski \& Dirshmit, 1988), and budget control in relation to changes in accounting standards and their implementation at the sector level (Anessi-Pessina, Babera, Rota, Sicilia, \& Steccolini, 2012). However, it is still rare for literature to try to link budget control with the budget realization (Anessi-Pessina et al., 2012; Johansson \& Siverbo, 2014). Researches that attempts to link budget oversight or control with the budget realization are those done by Johansson and Siverbo (2014), Wirasedana et al. (2018), also Boukari and Veiga (2018). The lack of previous literature linking budget oversight and its realization proves that this study is important to do as an important part of evaluating the system of monitoring the effectiveness of public policies in improving public welfare.

The contribution of this study is that the authors modified several previous studies linking budget oversight with budget realization, such as the study of Johansson and Siverbo (2014) but also testing the accuracy of tight budget controls in public sector agencies in dealing with budget turbu- lence such as the study of Wirasedana et al. (2018). Both of these studies use tight budget control as the independent variable, budget deviation as the dependent variable, and budget turbulence as the control variable. Another previous study is study by Boukari and Vega (2018) which examine the political and institutional determinants of budget forecast errors. The independent variables used are election cycle, fiscal autonomy, the ideology of the incumbent government, and the margin of victory of the incumbent party with several political and economic factors as control variables. The three researchers have not tested the effect of budget forecast errors on budget deviations, so the purpose of this study is to examine the effect of estimating budget errors on budget deviations. Furthermore, the author involves the financial capability index in the role of increasing the effect of budget forecast errors on budget deviations.

\section{The Budget Forecast Errors and the Budget Deviation}

Budget deviations indicate the failure of governments in planning, implementing, monitoring and accountability for the budget, causing a budget surplus or deficit. In the political theory of the budget cycle, budget is a political tool or means used by regulators (Dubois, 2016). This condition occurs because the budget is one measurement of the achievement of government performance. The government gives important attention to the budgeting process to increase public expectations of the government's ability to improve public welfare. However, from the planning process until budget accountability budget deviations take place. This condition caused by asymmetry information between regulators as the agent and the public as the principal (Jensen \& Meckling, 1976). That is, regulators have more access and information than principals and the implementation of budget oversight 
is not carried out effectively.

The budget deviation is a manifestation of information asymmetry from the aspect of agency theory. This condition occurs because the local government as the agent has more information related to budget management, such as the various changes that occur in the budget and conditions of instability of resources to develop budgets. Meanwhile, the community as the principal only has information on financial reports published by the local government. The negative consequence is that those who have more information can benefit from this information asymmetry (Herianti, 2019).

Deficits occur because of errors in budget forecasts (Jonung et al., 2006). In other words, budget forecast errors lead to budget deviations. Ariffianto and Adhariani (2018) explain that budget behavior is motivated by self-interest, myopic behavior, and dependence on the central government which will affect the budget surplus. The result is the government estimates that the revenue budget is too high (optimistic), and the budget forecast is too low so that the budget variance appears either surplus or the budget deficit. Auerbach (1999) states that the forecast of revenue is an important input in designing fiscal policy, and forecast of more (optimistic) revenue can reduce people's welfare. Repeated forecasts of revenue that are too high and/or a forecast of expenditure that is too low at the local level affect the accumulation of the debt and the debt burden will reduce the funds available to provide services to the public, thereby reducing public welfare. Based on the description, the author proposes the following hypothesis.

H1: The budget forecast error has a positive effect on the budget deviation
The Budget Forecast Errors, Financial Capability Index, and Budget Deviation

Important factors that cause errors in the budget forecasts are uncertainty in the micro and macroeconomic environment, changes in government policy, and the ability of budget forecast by the governments. The first factor is an inherent factor that is difficult to control by the government, while the second and third factors can be controlled by the government. The point is that errors in the budget forecasts made by the governments are due to inherent factors or other factors. Error estimation in the budget resulting in the existence of variance whether it is surplus or deficit. Jonung et al. (2006) state that the emergence of budget forecast errors is due to the deficit. Deficits and surpluses referred to as budget deviations.

Budget forecast errors have the potential to increase budget deviation due to the role of the financial capability index. The financial capability index is a condition where the government has financial capability in financing public services to improve people's welfare. The financial capability index shows that the governments can actualize various public service programs. The higher financial capability index provides an opportunity for governments to increase budget forecast errors against budget deviation. The government estimation revenues that are too high (optimistic) and/or budget forecast that is too low for expenditure, resulting in higher budget deviations.

Samora (2010) states that regional financial capability shows how far regions can explore their financial resources to finance their needs without having to rely on central government assistance. Based on the description, the author proposes:

H2: The financial capability index has a posi- 
tive effect on the relationship between budget forecast error and budget deviation

Based on the development of the hypothesis, the research model can be visualized in Figure 1.

\section{RESEARCH METHOD}

This study used the budget reports, the realization of revenue, and the expenditure budget of the local government throughout Indonesia for the period of 2015-2018. However, the analysis period is 2016-2018, considering the year 2015 used as the base year in calculating research variables. Data are obtained through the website of the Directorate General of Fiscal Balance through the website www.djpk.kemenkeu.go.id. The research sample is the local government throughout Indonesia for the period 2016-2018. The sampling technique uses purposive sampling according to several criteria in Table 1.
This study used descriptive statistics to provide a brief description of the variables of this study. The main variables are budget forecast error, financial capability index, and budget deviation. Author also uses local government's financial independence and economic ratios as control variables. The operational definitions of each variable are presented in Table 2.

\section{RESULT AND DISCUSSION}

Descriptive statistics of each variable are presented in Table 3. The average local government's failure to plan, implement, monitor, and be responsible for the budget that results in a budget surplus or deficit is 2.56. It shows that the budget deviation that comes from the comparison between the budget and the realization is quite significant. Meanwhile, the average budget forecast error of 0.227 indicates that the local government estimates the budget too high for revenue and/or too low for expendi-

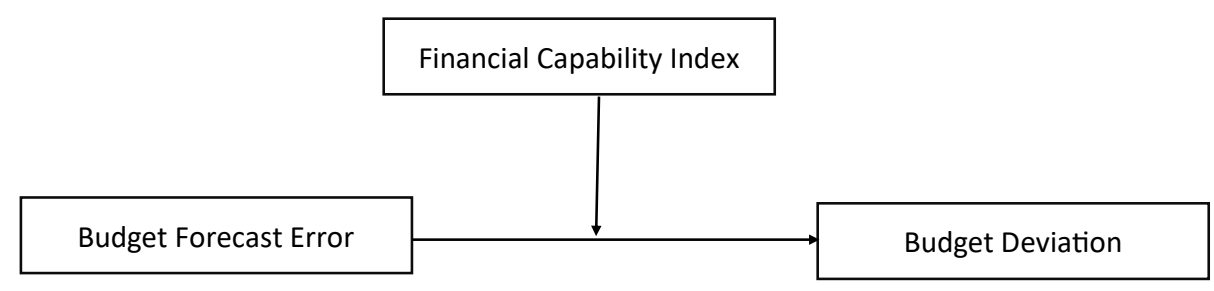

Figure 1. Research Model

Table 1. Sample Selection Process

\begin{tabular}{|c|c|c|c|}
\hline No. & Criteria & Yes & No \\
\hline 1. & Local governments registered on the Ministry of Finance's DJPK website for 2016-2018 & 508 & - \\
\hline 2. & Budget report and budget realization published in succession during the $2016-2018$ period & 443 & 65 \\
\hline & Number of Samples & \multicolumn{2}{|c|}{443} \\
\hline & Period & \multicolumn{2}{|c|}{3 Years } \\
\hline & Total Sample Observations & \multicolumn{2}{|c|}{1.329} \\
\hline
\end{tabular}

Source: Directorate General of Fiscal Balance processed by author 
ture by $22.7 \%$. Furthermore, the role of the financial capability index shows an average value of 0.128 . This value proves that the regional financial capability of the local government is $12.8 \%$. The interaction between the estimated budget forecast error and the financial capability index shows o.039. Those indicate that the financial capability index can cause an estimate of a budget forecast errors of 3.9\%. Furthermore, for the variable regional financial independence and economic ratio shows the average percentage of $12.4 \%$ and $52.4 \%$. This value proves that local governments in Indonesia are able to meet their needs and carry out operational activities economically. The standard deviation of the study variables shows the variability in this research data.

The correlation between variables shows the strength of the relationship between the research variables (presented in Table 4).

Table 2. Operational Variable Definition

\begin{tabular}{l}
\hline \multicolumn{1}{c}{ Definition } \\
$\begin{array}{l}\text { Budget Forecast Errors (PFE) } \\
\text { Budget forecast that are too high for } \\
\text { revenue and/or budget forecast that } \\
\text { are too low for expenditure. }\end{array}$ \\
$\begin{array}{l}\text { PFE } \\
\text { (Adapted from Boukari \& Veiga, 2018) }\end{array}$
\end{tabular}

Financial Capability Index (FCl) A condition where the government has the financial capacity to finance public services to improve public welfare.

$$
\frac{\text { Growth Index }+ \text { Elasticity Index }+ \text { Share Index }}{3}
$$

Ratio

Where:

$$
\begin{aligned}
& \text { Growth Index }=\frac{(\text { Actual Local Revenue }+ \text { Actual Sharing Revenue Fund }) t+}{(\text { Actual Local Revenue }+ \text { Actual Sharing Revenue Fund }) t-1} \\
& \text { Share Index }=\frac{(\text { Actual Sharing Revenue Fund }) t-1}{\text { Actual Expenditure }} \\
& \text { Elasticity Index }=\frac{\text { Actual Direct Expenditure }}{\text { Actual Revenue }}
\end{aligned}
$$

(Adapted from Samora, 2010; Bapenas, 2003)

Budget Deviation (DVA) Regulatory failure in planning, implementing, supervising, and accountable for the budget, resulting in a budget surplus or deficit.

(Adapted from Johansson \& Siverbo, 2014)

Financial Independence (FIN)

The ability of local governments to meet their needs.
Ratio

$$
\frac{\text { Actual Expenditure }}{\text { Budget Expenditure }}
$$

$\frac{\text { Budget Expenditure }}{\text { Actual Expenditure }}$

(Adapted from Risyanto, 2015)

$$
\frac{\text { Actual Local Revenue }}{\text { Actual Expenditure }}
$$

(Adapted from Kurrohman, 2013) 
Table 3. Descriptive Statistic

\begin{tabular}{|c|c|c|c|c|}
\hline & Variables & $\mathbf{N}$ & Mean & Deviation Standard \\
\hline & DVA & 1.329 & 2.561511 & 1.265084 \\
\hline & PFE & 1.329 & 0.2276058 & 0.2615374 \\
\hline & $\mathrm{FCl}$ & 1.329 & 0.1281892 & 0.7601012 \\
\hline & FCIPFE & 1.329 & 0.0397204 & 0.7601012 \\
\hline & FIN & 1.329 & 0.1243626 & 0.1578747 \\
\hline & ECR & 1.329 & 0.5242944 & 0.1578747 \\
\hline \multicolumn{5}{|l|}{ Notes: } \\
\hline DVA & \multicolumn{4}{|c|}{ : Budget Deviation } \\
\hline PFE & \multicolumn{4}{|c|}{ : Budget Forecast Errors } \\
\hline $\mathrm{FCl}$ & \multicolumn{4}{|c|}{ : Financial Capability Index } \\
\hline FCIPFE & \multicolumn{4}{|c|}{ : Interaction between the Financial Capability Index and Budget Forecast Errors } \\
\hline FIN & \multicolumn{4}{|c|}{ : Financial Independence } \\
\hline ECR & \multicolumn{4}{|c|}{ : Economics Ratio } \\
\hline
\end{tabular}

The strongest correlation value is the economic ratio and the budget forecast errors with the direction of the correlation are negative (-0.5640). This value indicates that when the economic ratio is high, the budget forecast errors will decrease. Conversely, when the economic ratio is low, the budget forecast errors will increase. This condition proves that the economic actions of the local governments have an important role in the budget forecast errors.

The author uses the rules of Baron \& Kenney (1986) to test the main effects and moderating effects. Table 5 shows the main effect test results and Table 6 shows the results of the test for moderation effects. The main effect test results prove that budget forecast errors have a positive and significant effect on the budget deviation. The findings of this study prove that $\mathrm{H}_{1}$ is supported. Budget forecast errors that occur in the local governments can increase the occurrence of budget deviation. The real form of budget deviation is budget variance, namely surplus and deficit. Jonung et al. (2006) explain that budget forecast errors can increase deficits in implementation and budget accountability. That is, the forecast of revenue that is too high continuously and/or the forecast of expenditure that is too low can cause a large accumulation of debt, so the debt burden will

Table 4. Correlation

\begin{tabular}{cccccc}
\hline Variables & PFE & FCI & FCIPFE & FIN & \\
\hline PFE & 1.0000 & & & & \\
\hline FCl & 0.0531 & 1.000 & & & \\
\hline FCIPFE & -0.2652 & -0.3236 & 1.0000 & 1.0000 & 1.0000 \\
\hline FIN & 0.1221 & 0.0286 & 0.0335 & -0.1244 & 0.0275 \\
\hline ECR & -0.5640 & 0.3432 & & & \\
\hline
\end{tabular}

\section{Notes:}

PFE : Budget Forecast Errors

$\mathrm{FCl} \quad$ : Financial Capability Index

FCIPFE : Interaction between Financial Capability Index and Budget Forecast Errors

FIN : Financial Independence

ECR : Economics Ratio 
reduce the availability of public goods and ultimately harm the public welfare.

The results of the moderation effect test prove that the financial capability index has a positive and significant effect on the relationship between budget forecast errors and budget deviations. Thus $\mathbf{H}_{2}$ is supported. The local governments have the ability to actualize various public service programs to improve public welfare.

The findings of this study are consistent with the results of the main test that the regional financial capability index can increase the occurrence of budget deviation. Furthermore, the regional financial capability index can increase the occurrence of budget forecast errors that will have an impact on budget deviations. The higher the regional capability index of a local government, the greater the potential for budget forecast errors that will affect budget deviation.

The research sample is divided into quadrant methods. The aim is to classify the financial capability of local governments to find out budget forecast errors and budget deviations at the quadrant level. The division of the quadrant method category adopts a study by Samora (2010) and Bappenas (2003). Samora (2010) and Bappenas (2003) describe each quadrant as follows.

1. Quadrant I is the most ideal condition. Local revenue and revenue sharing have an important role in total expenditure and regions have the ability to develop local potential. This condition is indicated by the magnitude of the share value accompanied by high growth values. This quadrant is categorized as an independent and potential área.

2. Quadrant II is a condition that is not yet ideal. However, regions have the ability to develop local potential so that local revenue has the potential to play a large role in total expenditure, the contribution of revenue sharing funds to total expenditure is still low but the growth of local revenue and high revenue-sharing funds. This quadrant is categorized as a nonindependent and potential region.

3. Quadrant III is a condition that is also not ideal. The role of local revenue and profit

Table 5. Main Effect Test

\begin{tabular}{lccc}
\multicolumn{1}{c}{ Independent Variables } & Expectation Sign & $\begin{array}{c}\text { Least Square Method } \\
\text { Dependent Variable: DVA }\end{array}$ & t-statistic \\
\hline PFE & + & Coefficient & $3.32^{* * *}$ \\
\hline FIN & - & 0.232102 & -1.41 \\
\hline ECR & - & -0.1358148 & $-60.44^{* * *}$ \\
\hline Constant & \pm & -3.670957 & $94.19^{* * *}$ \\
\hline F-Statistic & 4.450235 & \\
\hline $\mathrm{R}^{2}$ & $1901.75^{* * *}$ & \\
\hline Adjusted R & & 0.8115 & \\
\hline Root MSE & 0.8111 & \\
\hline Spesification Error F-Statistic & 0.54984 & \\
\hline Durbin-Watson Statistic & $3178.36^{* * * *}$ & 1.65515 \\
\hline $\mathrm{N}$ & 1.329 & \\
\hline
\end{tabular}

Note: Free of specification error, multicollinearity, and autocorrelation. Significant at: $* * * 1$ percent level. 
sharing funds in total expenditure has a small chance because of the growth of local revenue and profit sharing funds against high total expenditure. However, growth in local revenue and low profit sharing funds. This quadrant is categorized as an independent region and has less potential.

4. Quadrant IV is the worst condition. Local revenue and revenue sharing have not taken a large role in total expenditure and the regions do not yet have the ability to develop local potential. Regional revenue and profit sharing funds towards total expenditure are low and local revenue growth and profit sharing funds are low. This quadrant is categorized as an region that is not independent and has less po- tential.

The correlation of the research variables in the I-IV quadrant are shown in the Appendix 4. The strongest correlation value is the economic ratio and budget forecast error with negative correlation direction in quadrants I - IV. The negative direction of the relationship shows that when the economic ratio is high, the budget forecast error will decrease. Conversely, when the economic ratio is low, the budget forecast error will increase.

The result of the sensitivity test of the main effect and moderating effect on the quadrant presented in the appendix. The findings of the main effect study prove that budget

Table 6. Moderating Effect Test

\begin{tabular}{|c|c|c|c|c|}
\hline \multirow{2}{*}{\multicolumn{2}{|c|}{ Independent Variables }} & \multirow{2}{*}{ Expectation Sign } & \multicolumn{2}{|c|}{$\begin{array}{c}\text { Least Square Method } \\
\text { Dependent Variable: DVA }\end{array}$} \\
\hline & & & Coefficient & t-statistic \\
\hline \multicolumn{2}{|l|}{ PFE } & + & 0.2507819 & $3.34 * * *$ \\
\hline \multicolumn{2}{|l|}{$\mathrm{FCl}$} & + & 0.0682712 & $2.94 * * *$ \\
\hline \multicolumn{2}{|l|}{ FCIPFE } & + & 0.0953744 & $3.84 * * *$ \\
\hline \multicolumn{2}{|l|}{ FIN } & - & -0.1762449 & $-1.83^{*}$ \\
\hline \multicolumn{2}{|l|}{ ECR } & - & -3.72928 & $-55.01 * * *$ \\
\hline \multicolumn{2}{|c|}{ Constant } & \pm & 4.46905 & $87.65 * * *$ \\
\hline \multicolumn{2}{|c|}{ F-Statistic } & & 1158.84 & \\
\hline \multicolumn{2}{|l|}{$\mathrm{R}^{2}$} & & 0.8141 & \\
\hline \multicolumn{2}{|c|}{ Adjusted $\mathrm{R}^{2}$} & & 0.8134 & \\
\hline \multicolumn{2}{|c|}{ Root MSE } & & 0.54647 & \\
\hline \multicolumn{2}{|c|}{ Spesification Error F-Statistic } & & $2378.05 * * *$ & \\
\hline \multicolumn{2}{|c|}{ Durbin-Watson Statistic } & & 1.64974 & \\
\hline \multicolumn{2}{|l|}{$\mathrm{N}$} & & 1.329 & \\
\hline \multicolumn{5}{|l|}{ Notes: } \\
\hline \multicolumn{5}{|c|}{ Free of specification error, multicollinearity, and autocorrelation. Significant at: ${ }^{*} 10, * * 5$ and $* * * 1$ percent levels. } \\
\hline DVA & : Budget Deviation & & & \\
\hline PFE & : Budget Forecast $\mathrm{E}$ & & & \\
\hline $\mathrm{FCl}$ & : Financial Capabilit & & & \\
\hline FCIPFE & : Interaction betwe & Capability Index & ecast Errors & \\
\hline FIN & : Financial Indepenc & & & \\
\hline ECR & : Economics Ratio & & & \\
\hline
\end{tabular}


forecast errors have a positive and significant effect on budget deviations only in quadrants I and II. Meanwhile, quadrants III and IV indicate that budget forecast errors do not have a significant effect on budget deviation. This finding is consistent with the results of the previous main test which proves that a high regional financial capability index has the potential to cause budget forecast errors that have an impact on increasing budget deviation. Quadrant I is a category for local governments that has independence and has the potential to improve performance. This condition is supported by the role of local revenue and revenue sharing in supporting local expenditure. Furthermore, quadrant II, where the local government is not independent but has the potential to improve its performance, can cause budget forecast errors that will affect budget deviation. This condition occurs because local revenue has an important role in total regional expenditure. Meanwhile, Quadrants III and IV are still classified as less potential regions, so that budget forecast errors are not significant in influencing budget deviation.

In contrast to the results of the main effect test, the results of the moderating effect test prove that the role of the regional financial capability index in increasing the effect of budget forecast errors on budget deviations is evident in all quadrants, except Quadrant II. This result proves that the involvement of regional financial capability index in independent and potential regions (Quadrant I), independent and less potential (Quadrant III), and not self-sufficient and less potential (Quadrant IV) has the potential to support budget forecast errors.

Table 7 shows that the average budget forecast error and budget deviation for Quadrant I is higher than Quadrants II, III, and IV. This condition proves that errors in estimating the budget and budget deviations of local governments in Indonesia during the 2016-2018 period tend to occur in the local governments which are categorized as independent and potential (Quadrant I).

A different test was conducted on the whole quadrants (I - IV) to test the difference between each quadrant against errors in budget forecast and budget deviation. Table 8 shows the results of the multivariate test to

Table 7. Percent Forecast Error and Budget Deviation for Each Quadrant

\begin{tabular}{|c|c|}
\hline \multicolumn{2}{|c|}{ Percent Forecast Error (PFE) } \\
\hline $\begin{array}{l}\text { Quadrant II } \\
(\mathrm{N}=248) \\
(\text { Mean }=0.19) \\
(\text { Std. }=0.18)\end{array}$ & $\begin{array}{c}\text { Quadrant I } \\
(\mathrm{N}=247) \\
(\text { Mean }=0.30) \\
\text { (Std. }=0.15)\end{array}$ \\
\hline $\begin{array}{l}\text { Quadrant IV } \\
(\mathrm{N}=607) \\
(\text { Mean }=0.21) \\
(\text { Std. }=0.33)\end{array}$ & $\begin{array}{l}\text { Quadrant III } \\
(\mathrm{N}=227) \\
(\text { Mean }=0.20) \\
\text { (Std. }=0.19)\end{array}$ \\
\hline \multicolumn{2}{|c|}{ Budget Deviation (DVA) } \\
\hline $\begin{array}{l}\text { Quadrant II } \\
(\mathrm{N}=248) \\
(\text { Mean }=2.20) \\
(\text { Std. }=1.14)\end{array}$ & $\begin{array}{c}\text { Quadrant I } \\
(\mathrm{N}=247) \\
(\text { Mean }=2.76) \\
\text { (Std. = 1.03) }\end{array}$ \\
\hline $\begin{array}{l}\text { Quadrant IV } \\
(\mathrm{N}=607) \\
(\text { Mean }=2.70) \\
(\text { Std. }=1.36)\end{array}$ & $\begin{array}{l}\text { Quadrant III } \\
(\mathrm{N}=227) \\
(\text { Mean }=2.35) \\
\text { (Std. }=1.23)\end{array}$ \\
\hline
\end{tabular}


Table 8. Multivariate Test

\begin{tabular}{cccc}
\hline Source & & Statistics & F-Statistic \\
\hline & Wilks' Lambda & 0.9537 & $10.58^{* * *} \mathrm{e}$ \\
Quadrant & Pillai's Trace & 0.0468 & $10.58^{* * *} \mathrm{a}$ \\
& Lawley-Hotelling Trace & 0.0480 & $10.59^{* * *} \mathrm{a}$ \\
& Roy's Largest Root & 0.0307 & $10.58^{* * *} \mathrm{u}$ \\
\hline
\end{tabular}

find out each quadrant affects the group budget forecast errors and budget deviation. The findings prove that local governments are categorized as independent and potential (Quadrant I), not independent and potentially (Quadrant II), independent and less potential (Quadrant III), and not selfsufficient and less potential (Quadrant IV) against errors in budget forecast and budget deviations. This is indicated by the value of Lawley-Hotelling Trace which is significant at level 1\% (Lawley-Hotelling Trace is used for two groups of dependent variables).

Table 9 is used to test the effect of univariate ANOVA for each quadrant on budget forecast errors and budget deviation. The findings prove that there are differences between local governments that are categorized as independent and potential (Quadrant I), not independent and potentially (Quadrant II), independent and less potential (Quadrant III), and not self-sufficient and less potential (Quadrant) IV) against budget estimation errors and budget deviations. This is indicated by the $\mathrm{F}$ statistic value at level $1 \%$.

Table 10 is used to test for differences in budget forecast errors and budget deviation for four categories of quadrants. The findings show that budget forecast errors differ between local governments that are categorized as non-independent and potential regions (Quadrant II) with local governments which are categorized as independent and potential regions (Quadrant I), budget forecast errors differ between local governments which are categorized as independent and less potential regions (Quadrant III) with local governments which are categorized as independent and potential regions (Quadrant I), and budget forecast errors differ between the local which is categorized as a non-independent and less potential regions (Quadrant IV) with the local government which is categorized as an independent and potential regions (Quadrant I).

Table 9. Test of Between-Subject Effects

\begin{tabular}{ccccc}
\hline \multicolumn{5}{c}{ Percent Forecast Error (PFE) } \\
\hline Source & SS & Df & MS & F \\
\hline Between Groups & 1.96790955 & 3 & 0.655969851 & $9.78^{* * *}$ \\
\hline Within Groups & 88.8696694 & 1325 & 0.067071449 & F \\
\hline Total & 90.8375789 & 1328 & 0.068401791 & $13.54^{* * *}$ \\
\hline Source & SS & Budget Deviation (DVA) & MS & \\
\hline Between Groups & 63.2216448 & Df & 3 & 1.55634729 \\
\hline Within Groups & 2062.16016 & 1325 & 1.60043811 & \\
\hline Total & 2125.38181 & 1328 & & \\
\hline
\end{tabular}


Table 10. Multiple Comparisons

\begin{tabular}{|c|c|c|c|}
\hline \multicolumn{4}{|c|}{ Percent Forecast Error (PFE) } \\
\hline Quadrant & Contrast & Std. Error & t-Statistic \\
\hline 2 vs 1 & -0.1146972 & 0.0232808 & $-4.93 * * *$ \\
\hline 3 vs 1 & -0.0986373 & 0.023812 & $-4.14 * * *$ \\
\hline 4 vs 1 & -0.085601 & 0.0195459 & $-4.38 * * *$ \\
\hline 3 vs 2 & 0.01606 & 0.023789 & 0.68 \\
\hline 4 vs 2 & 0.0290962 & 0.0195178 & 1.49 \\
\hline 4 vs 3 & 0.0130362 & 0.0201486 & 0.65 \\
\hline \multicolumn{4}{|c|}{ Budget Deviation (DVA) } \\
\hline Quadrant & Contrast & Std. Error & t-Statistic \\
\hline 2 vs 1 & -0.5587306 & 0.1121454 & $-4.98 * * *$ \\
\hline 3 vs 1 & -0.4036231 & 0.1147046 & $-3.52 * * *$ \\
\hline 4 vs 1 & -0.0593071 & 0.0941541 & -0.63 \\
\hline 3 vs 2 & 0.1551075 & 0.1145938 & 1.35 \\
\hline 4 vs 2 & 0.4994235 & 0.0940191 & $5.31 * * *$ \\
\hline 4 vs 3 & 0.344316 & 0.0970575 & $3.55^{* * *}$ \\
\hline
\end{tabular}

The findings of this study prove that the local governments that are categorized as independent and potential (Quadrant I) have greater average budget forecast errors than the local government which is categorized as a non-autonomous and potential (Quadrant II), independent and less potential (Quadrant III), and not self-sufficient and less potential (Quadrant IV). Local governments that are classified as independent and potentially have high share and growth values. Both of these values contribute significantly to total regional expenditure in increasing public prosperity.

Table 10 also shows that (1) budget deviations differ between local governments which are categorized as non-independent and potential regions (Quadrant II) and local governments categorized as independent and potential regions (Quadrant I). Budget deviation of the local government in Quadrant III also differ with local governments that are categorized as independent and potential regions (Quadrant I). The local governments in Quadrant I have a larger average budget deviation than the local government in Quadrant II and Quadrant III. Budget deviation between local governments that are categorized as nonindependent and less potential regions (Quadrant IV), local governments that are categorized as non-independent and potential regions (Quadrant II), and local governments which are categorized as independent and less potential regions (Quadrant III) are different.

Furthermore, the local government which is categorized as a non-independent and less potential region (Quadrant IV) has a larger average budget deviation than the local government in Quadrant II and Quadrant III. Local governments that are classified as not independent and have less potential have low share and growth values. Local governments that are categorized as non-independent and less potential have the possibility to increase budget deviations compared to other local government categories. This 
condition is caused by the lack of inaccurate budget forecast both at the level of revenue and expenditure, so that it has the potential to increase the budget surplus or deficit.

\section{CONCLUSION}

The findings of this study prove that budget forecast error has positive and significant effect on budget deviation, and financial capability index has a positive and significant effect on the relationship between budget forecast errors and budget deviation. The sensitivity test results prove that there is consistency with the findings of the main test results. Moreover, additional test results also prove the existence of consistency with the main test findings. This is indicated by the results of the local government category test with the quadrant method.

This study has implication for the development of theory, especially agency theory and budget cycle political theory. This study shows that agency theory has an important role in creating information asymmetry between governments and the public. Information asymmetry triggers an error in budget forecast affecting the budget deviation. This happens because governments have access and more information related to the availability of resources in planning and implementing budgets. Meanwhile, the public can only access information through publication of financial statements. Delegation of authority given by the public to the legislature to reduce information asymmetry cannot guarantee that the government has carried out public service activities properly. This is because information on regional resources is better known by the governments than the legislature. The legislature is the party that plays a role in ratifying the budget, while planning to implementation process is the responsibility of the government.
The study implication for the research methodology is the use of several methods of analysis and evaluating the effect of budget forecast errors on budget deviations with the financial capability index as a moderating variable. The author uses STATA analysis tool version 15.1 to test the research hypothesis. This analysis tool is still rarely used in the public sector accounting research literature. One of the advantages of this analysis tool is that author can test error specifications, thereby reducing the decisionmaking bias.

The implications of this study for policy are (1) the priority of the policy program of the local governments to improve the quality of public services. This condition is important for the governments because it can reduce spending inefficiencies that often occur in public sector agencies. Expenditure inefficiencies represent a budget deficit. The limited resources that enable non-optimal revenue require the governments to design effective, efficient and economical budgets; (2) the application of SWOT analysis to prevent and overcome the uncertainty of the micro and macroeconomic environment, as well as fiscal policies carried out by the governments, thereby reducing errors budget forecast that have an impact on budget deviations; (3) evaluating the performance of the governments related to the financial capability index, thereby reducing the existence of inefficiency activities in improving the quality of public services.

The limitations, of this study are (1) measurement of budget forecast and budget deviations that are still limited in public sector accounting research, so this study uses only a proxy estimate of budget forecast used by Boukari and Veiga (2018) also budget deviation proxies used by Johansson and Siverbo (2014); (2) generalizing the results of this study only to local governments in Indonesia during the period 2016-2018; (3) limited 
data on the publication of 2018 local revenue and expenditure budgets totaling 443 local governments from 508 local governments. Thus, further research can develop a proxy for measuring budget forecast errors and budget deviations, providing added value for research contributions, use central government samples through a sample of ministries and agencies, and modify this study using several research variables, such as budget turbulence or tight budget control to answer research issues.

\section{REFERENCES}

Anessi-Pessina, E., Barbera, C., Rota, S., Sicilia, M., \& Steccolini, I. (2012). Public sector budgeting in European accounting and public management iournals: A review In: presented at 7 th International Conferences on Accounting, Auditing \& Management in Public Sector Reform. Rome.

Ariffianto, M., \& Adhariani, D. (2018). Budget surplus determinants in Indonesian Regional Government Budgets from a budgetary slack behaviour point of view. International Journal of Economics and Management, 12(1), 17-29.

Auerbach, A. J. (1999). On the performance and use of government revenue forecast. National Tax Journal, 52(4), 767-782.

Bappenas. (2003). Peta kemampuan keuangan daerah provinsi dalam era otonomi daerah: Tinjauan kinerja PAD, dan upaya yang dilakukan daerah. Direktorat Pengembangan Otonomi Daerah.

Baron, R. M., \& Kenney, D. (1986). The moderator-mediator variable distiction in social psychological research: Conceptual, strategic, and statistical considerations. Journal of Personality and Social Psychology, 51(6), 11731182. doi: 10.1037/0022-3514.51.6.1173
Boland, R. J., \& Pondy, L. R. (1986). The micro dynamics of a budget-cutting process: Modes, models and structure. Accounting Organizations Social, 11(55), 403-422. doi: 10.1016/0361-3682 (86)90010-3.

Boukari, M., \& Veiga, F. J. (2018). Disentangling political and institutional determinants of budget forecast errors: A comparative approach. Journal of Comparative Economics, 46(4), 1030-1045. doi: 10.1016/j.jce.2018.03.002

Covaleski, M. A., \& Dirshmit, M. W. (1988). The use of budgetary symbols in the political arena: An historically informed field study. Accounting Organizations and Society, 13(1), 1-24. doi: 10.1016/0361-3682(88)90023-2

Directorate General of Fiscal Balance. (n.d.). Laporan realisasi anggaran. Retrieved from http:// www.djpk.kemenkeu.go.id/? page_id $=316$

Dubois, E. (2016). Political business cycles 40 years after Nordhaus. Public Choice, 166(1-2), 235-259. doi: 10.1007/s11127016-0313-z

Herianti, E. (2019). Budget turbulence and budget deviation: Do local government have the ability to reduce them?. Jurnal Tata Kelola \& Akuntabilitas Keuangan Negara, 5(1), 1-20. doi: 10.28986/jtaken.v5i1.285

Jensen, M. C., \& Meckling, W. H. (1976). Theory of the firm: Managerial behavior, agency cost, and ownership structure. Journal of Financial Economics, 3(1976), 305-360.

Johansson, T., \& Siverbo, S. (2014). The appropriateness of tight budget control in public sector organizations facing budget turbulence. Management Accounting Research, 25(4), 271-283. doi: 10.1016/j.mar.2014.04.001

Jonsson, S. (1982). Budget behavior in local government: A case study over 3 years. Accounting Organization Society, 7(3), 287-304. doi: 10.1016/0361-3682(82) 


\section{5-8}

Jonung, L., Larch, M., Favero, C. A., \& Martin, P. (2006). Improving fiscal policy in the EU: The case for independent forecast. Economics Policy, 21(47), 491-534.

Kurrohman, T. (2013). Evaluasi penganggaran berbasis kinerja melalui kinerja keuangan yang berbasis value for money di kabupaten/kota di Jawa Timur. Jurnal Dinamika Akuntansi, 5 (1), 1-11.

Risyanto, H. (2015). Analisis kemampuan keuangan daerah dan kemandirian keuangan daerah serta pengaruhnya terhadap pertumbuhan ekonomi Kabupaten Garut tahun anggaran 2004 -2013. Coopetition, VI(1), 21-33.
Samora, R. (2010). Peta kemampuan keuangan daerah pada pemerintah kota dan kabupaten Se-Jawa dan Bali tahun 2004-2008: Metode kuadran. Jurnal Akuntansi Kontemporer, 2(1), 65-84.

Siregar, B. (2017). Akuntansi sektor publik: akuntansi keuangan pemerintah daerah berbasis akrual. Edisi Kedua. Yogyakarta: UPP STIM YKPN.

Wildavsky, A. (1975). Budgeting: A comparative theory of budget processes. Little. Brown \& Co., Boston.

Wirasedana, I. W. P., Sisdyani, E. A., \& Setiawan, I. P. E. (2018). Kendali budget ketat pada Pemda di Provinsi Bali dalam menghadapi turbulensi budget. E-Jurnal Akuntansi Universitas Udayana, 25(1), 300-327. doi: 10.24843/EJA.2018.v25.io1.p12 


\section{APPENDICES}

Appendix 1. Sensitivity Test of Moderating Effect (Dummy FCl)

\begin{tabular}{|c|c|c|c|}
\hline \multirow{2}{*}{ Independent Variables } & \multirow{2}{*}{ Expectation Sign } & \multicolumn{2}{|c|}{$\begin{array}{c}\text { Least Square Method } \\
\text { Dependent Variable: DVA }\end{array}$} \\
\hline & & Coefficient & t-statistic \\
\hline PFE & + & 0.1760228 & $2.53 * *$ \\
\hline $\mathrm{DFCl}$ & + & 0.1514501 & $2.70 * * *$ \\
\hline DFCIPFE & + & 0.6749743 & $3.15^{* * *}$ \\
\hline FIN & - & -0.2637018 & $-2.72 * * *$ \\
\hline ECR & - & -3.835986 & $-48.21 * * *$ \\
\hline Constant & \pm & 4.50968 & $91.11^{* * *}$ \\
\hline F-Statistic & & $1186.88^{* * *}$ & \\
\hline $\mathrm{R}^{2}$ & & 0.8177 & \\
\hline Adjusted $\mathrm{R}^{2}$ & & 0.8170 & \\
\hline Root MSE & & 0.54116 & \\
\hline Spesification Error F-Statistic & & $1605.46^{* * *}$ & \\
\hline Durbin-Watson Statistic & & 1.68105 & \\
\hline $\mathrm{N}$ & & 1.329 & \\
\hline
\end{tabular}

Notes : Free of specification error, multicollinearity, and autocorrelation. Significant at: $* 10, * * 5$ and $* * * 1$ percent levels. We used the category of regional financial capability adopted from Bapenas (2003). Bapenas (2003) classified the category of financial capability index into three low categories with a range of values $0.10-0.33$, medium category with a range of values $0.35-0.42$, and a high category with a range of $0.44-0.93$. Next, we divided the three categories into two parts to form variable dummy. Value 1 for high category, and value 0 for medium and low category.

DVA : Budget Deviation

PFE : Budget Forecast Errors

$\mathrm{DFCl} \quad$ : Dummy of Financial Capability Index

DFCIPFE : Interaction between Dummy of Financial Capability Index and Budget Forecast Errors

FIN : Financial Independence

ECR : Economics Ratio 


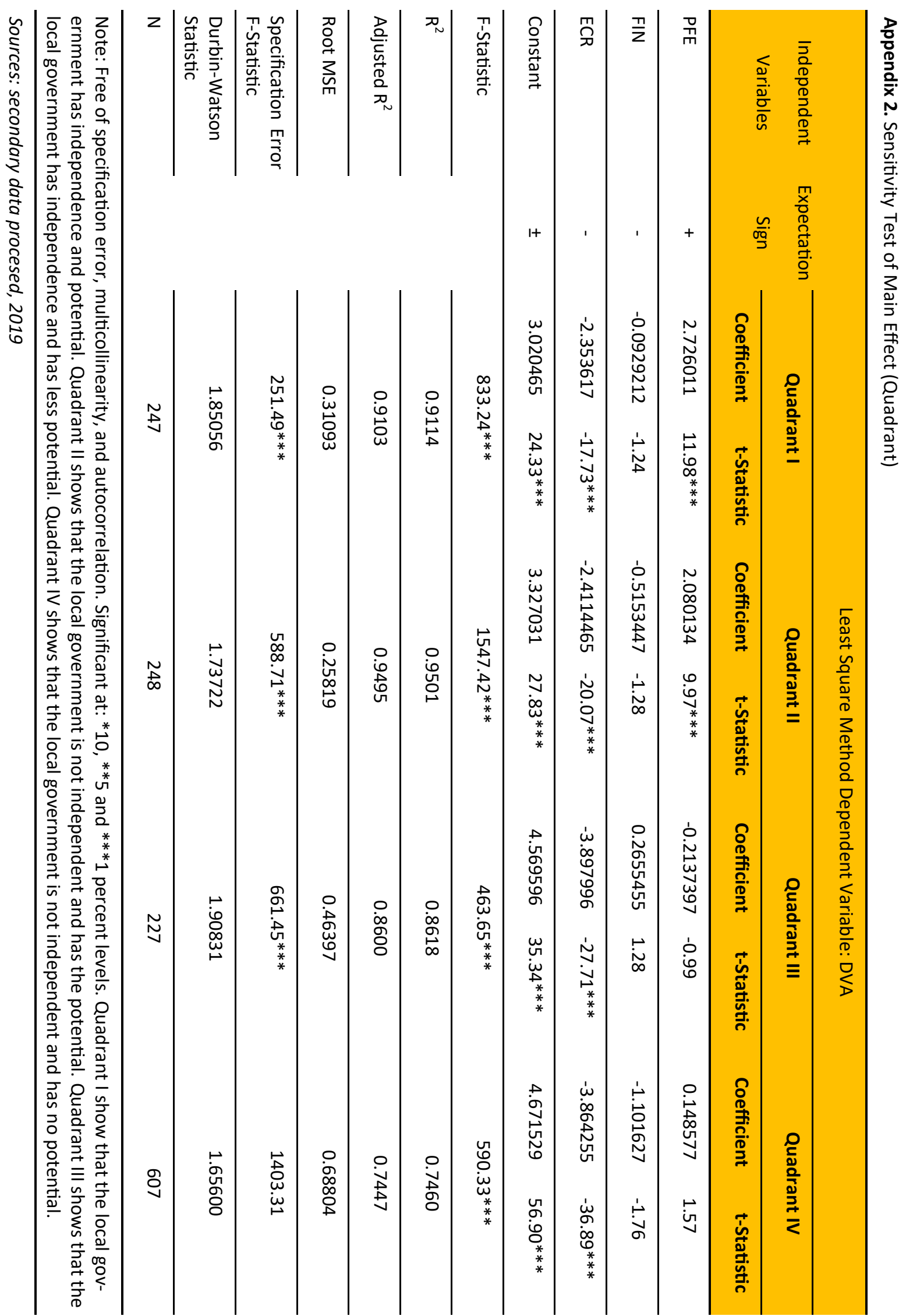




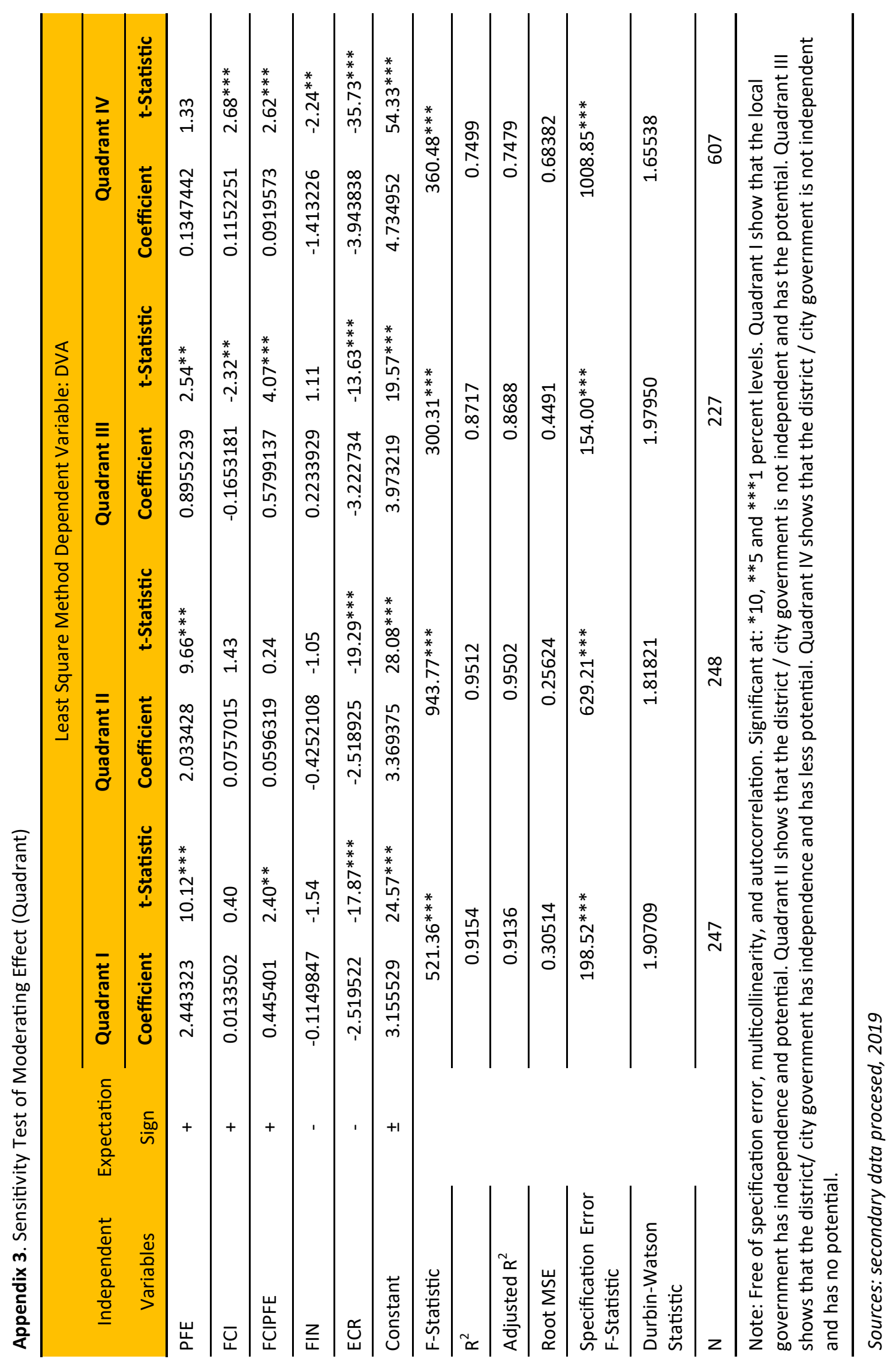


Appendix 4. Correlation in Each Quadrant

Quadrant I

\begin{tabular}{cccccc}
\hline Variables & PFE & FCI & FCIPFE & FIN & \\
\hline PFE & 1.0000 & & & & \\
\hline FCl & -0.2718 & 1.0000 & & & \\
\hline FCIPFE & 0.1934 & 0.5640 & 1.0000 & & \\
\hline FIN & 0.2231 & -0.0591 & 0.1547 & 1.0000 & 1.0000 \\
\hline ECR & -0.8217 & 0.4196 & 0.0311 & -0.1488 & \\
\hline
\end{tabular}

Quadrant II

\begin{tabular}{cccccc}
\hline Variables & PFE & FCI & FCIPFE & FIN & \\
\hline PFE & 1.0000 & & & \\
\hline FCI & -0.5337 & 1.0000 & & & \\
\hline FCIPFE & 0.0241 & 0.6125 & 1.0000 & & \\
\hline FIN & 0.2645 & -0.2582 & -0.1438 & 1.0000 & 1.0000 \\
\hline ECR & -0.9013 & 0.6225 & 0.0560 & -0.3110 & \\
\hline
\end{tabular}

Quadrant III

\begin{tabular}{cccccc}
\hline Variables & PFE & FCI & FCIPFE & FIN & ECR \\
\hline PFE & 1.0000 & & & & \\
\hline FCI & -0.0241 & 1.0000 & & & \\
\hline FCIPFE & -0.4499 & -0.0563 & 1.0000 & & \\
\hline FIN & 0.1695 & -0.0846 & 0.0378 & 1.0000 & 1.0000 \\
\hline ECR & -0.6725 & 0.5226 & -0.0305 & -0.2234 & \\
\hline
\end{tabular}

Quadran IV

\begin{tabular}{cccccc}
\hline Variables & PFE & FCI & FCIPFE & FIN & \\
\hline PFE & 1.0000 & & & & \\
\hline FCI & 0.0531 & 1.0000 & & & \\
\hline FCIPFE & -0.2625 & -0.3236 & 1.0000 & & \\
\hline FIN & 0.1221 & 0.0286 & 0.0335 & 1.0000 & 1.0000 \\
\hline ECR & -0.5640 & 0.3432 & 0.0275 & -0.1244 & \\
\hline
\end{tabular}

Notes:

PFE : Budget Forecast Errors

$\mathrm{FCl} \quad$ : Financial Capability Index

FCIPFE : Interaction between Financial Capability Index and Budget Forecast Errors

FIN : Financial Independence

ECR : Economics Ratio 


\section{Forecast}

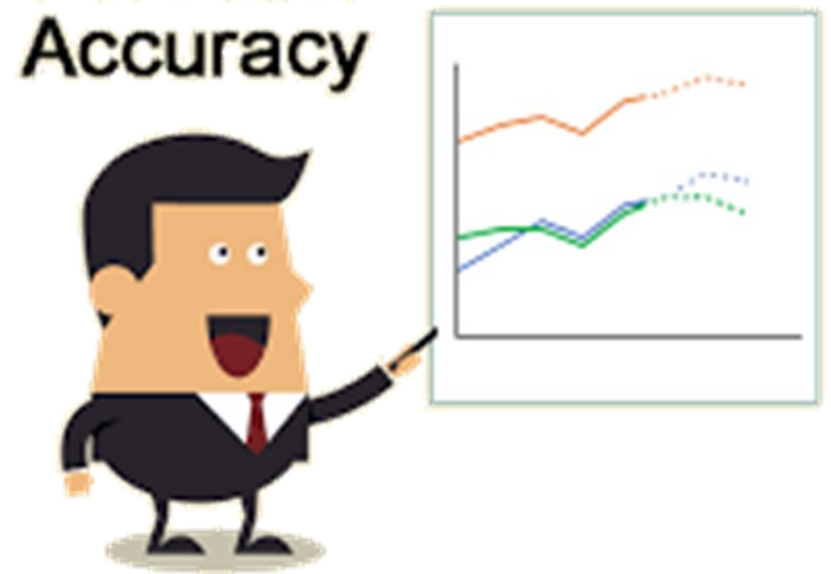

